\title{
Inmunoterapia sintética para infecciones por bacterias gram-positivas y gram-negativas
}

\author{
Sandoval-Valencia, Rodrigo Ricardo ${ }^{1^{*}}$ \\ ${ }^{1}$ Universidad Central del Ecuador. Facultad de Ciencias Médicas, Quito, Ecuador. \\ e-mail: ricardorsv44@gmail.com
}

\begin{abstract}
Palabras clave: Anticuerpos, infecciones bacterianas, inmunoterapia, métodos
\end{abstract} antibacterianos, opsonización.

INTRODUCCIÓN: La resistencia bacteriana a los antibióticos representa un problema importante de salud pública a nivel mundial. La continua aparición de microorganismos capaces de evadir fármacos tradicionales requiere un esfuerzo constante en el desarrollo de nuevas modalidades de tratamiento.

La inmunoterapia ha sido ampliamente estudiada como mecanismo alternativo para tratar ciertas neoplasias. Al momento, se están llevando a cabo estudios que reconocen la capacidad de respuesta del sistema inmunológico y utilizan su especificidad en el reconocimiento de antígenos.

OBJETIVO: Buscar alternativas terapéuticas frente a infecciones bacterianas resistentes

MATERIALES Y MÉTODOS: Se realizó una búsqueda bibliográfica sistemática sobre terapias alternativas frente a infecciones bacterianas utilizando las palabras clave descritas, así como un análisis sobre la utilización de inmunoterapia sintética frente a infecciones bacterianas.

RESULTADOS: Pang y colaboradores [1] plantean el uso de un anticuerpo monoclonal neutralizante frente a la toxina A de Staphylococcus aureus meticilino resistente (MRSA) genéticamente ensamblado en la superficie de nano partículas. Así, se actúa sobre la patogenicidad de la bacteria atacando directamente su virulencia. Por otro lado, al activarse un sonosensibilizador localizado en las nano partículas, a través de ondas de ultrasonido se generan especies reactivas de oxígeno en el lugar de la infección lo que conlleva a la destrucción final del microrganismo.

Feigamn y colaboradores [2] proponen la utilización de un nonapéptido de polimixina $B$ (PMBN) ligado a un hapteno (dinitrofenol) por medio de un espaciador. La molécula de PMBN desencadenará el reclutamiento de anticuerpos y células inmunitarias debido a la gran cantidad de anticuerpos anti-dinitrofenol en la circulación sanguínea. De esta manera se consigue la eliminación de la bacteria por un proceso de opsonización que desencadenará la activación del complemento y lisis bacteriana.

CONCLUSIONES: Debido a que las células inmunitarias ofrecen un reconocimiento específico antígeno- anticuerpo, la inmunoterapia previene el desarrollo de resistencia bacteriana al ofrecer un mecanismo de acción que potencia la actividad del sistema inmunitario, con lo que se logra evadir los efectos adversos provocados al utilizar tratamientos farmacológicos convencionales. Es evidente que la inmunoterapia sintética ofrece una posibilidad alentadora en la búsqueda de nuevas modalidades de tratamiento frente a infecciones bacterianas multiresistentes.

\section{REFERENCIAS:}

[1] Pang X, Liu X, Cheng Y, Zhang C, Ren E, Liu C et al. Sono-Immunotherapeutic Nanocapturer to Combat Multidrug-Resistant Bacterial Infections. Advanced Materials. 2019; 31(35).

[2] Feigman M, Kim S, Pidgeon S, Yu Y, Ongwae G, Patel D et al. Synthetic Immunotherapeutics against Gram-negative Pathogens. Cell Chemical Biology. 2018; 25(10):1185-1194. 